Document downloaded from:

http://hdl.handle.net/10251/44802

This paper must be cited as:

Bosch Roig, MDP.; Regidor Ros, JL.; Montes Estellés, RM. (2013). Biocleaning of nitrate alterations on wall paintings by Pseudomonas stutzeri. International Biodeterioration and Biodegradation. 84:266-274. doi:10.1016/j.ibiod.2012.09.009.

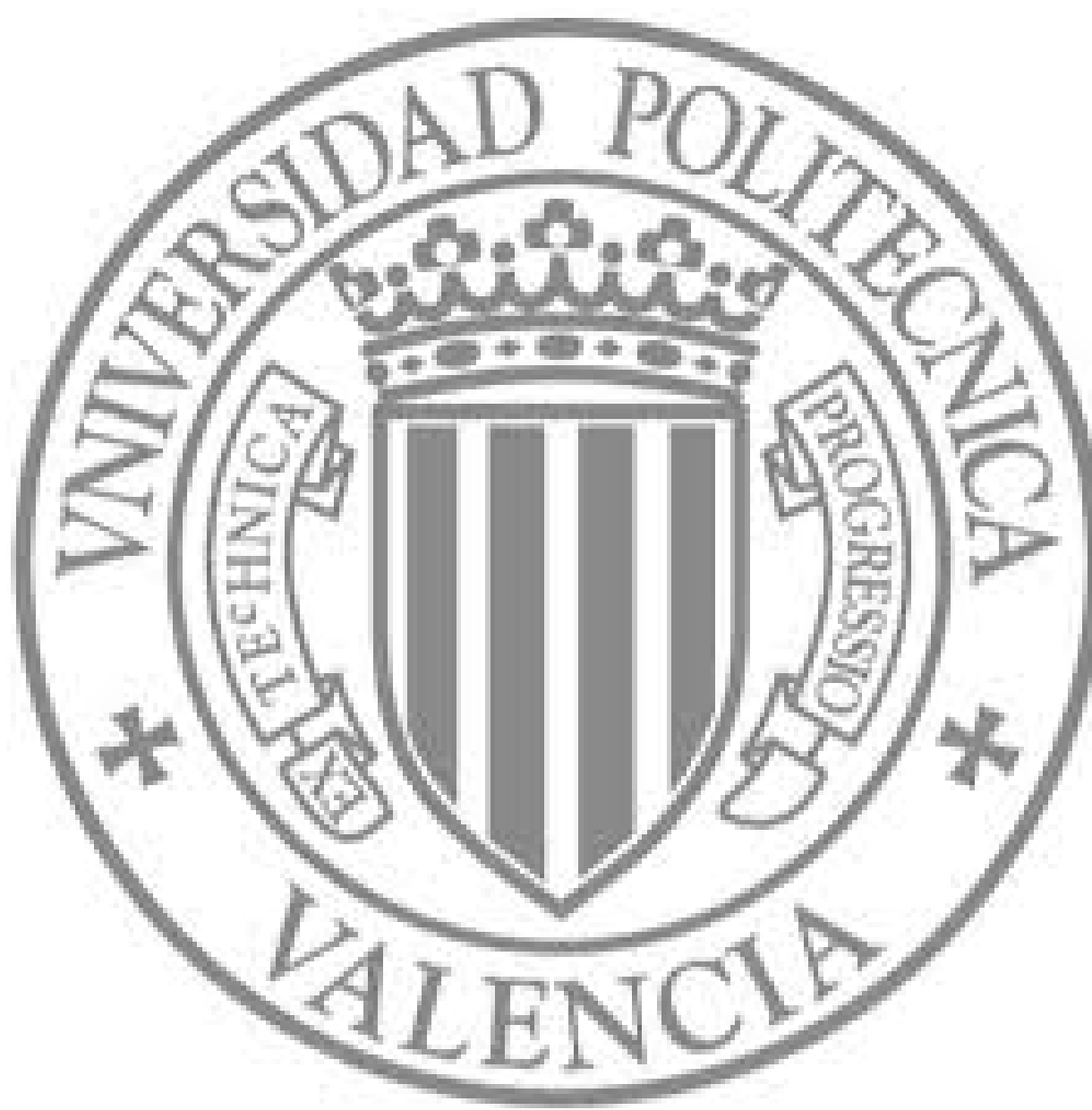

The final publication is available at

http://dx.doi.org/10.1016/j.ibiod.2012.09.009

Copyright Elsevier 
Elsevier Editorial System(tm) for International Biodeterioration \& Biodegradation Manuscript Draft

Manuscript Number:

Title: BIOCLEANING OF NITRATE ALTERATIONS ON WALL PAINTINGS BY PSEUDOMONAS STUTZERI

Article Type: Special Issue: IBBS-15 Vienna

Keywords: Biocleaning; Pseudomonas stutzeri; Bacteria; Mural Painting; Santos Juanes church; Nitratereducing bacteria.

Corresponding Author: Dr. Pilar Bosch Roig,

Corresponding Author's Institution: Instituto de Restauración del Patrimonio

First Author: Pilar Bosch Roig

Order of Authors: Pilar Bosch Roig; Jose Luis Regidor Ros; Rosa Montes Estellés

Abstract: The microorganisms have been considered as causative agents of biodeterioration in multiple art works; however, they can be positively used for cleaning of salt crusts difficult to remove by traditional restoration methods. Here we use Pseudomonas stutzeri to efficiently clean wall paintings. These bacteria are able to efficiently remove in a homogenous way insoluble salt efflorescence without damaging the painting layer by using a new application support consisting in agar. This new technology has been successfully applied for the biocleaning of an eighteen century murals in a lunette of the Santos Juanes Church of Valencia, Spain. 


\section{HIGHLIGHTS}

- $\quad$ P.stutzeri DSMZ 5190 viable cells show greater ability to convert nitrate to nitrogen gas

- $\quad$ Agar layer as carrier shows good characteristics for biocleaning technologies

- $\quad$ P. stutzeri cells efficiently remove nitrate salt efflorescence from wall paintings

- This approach is specific and respectful to wall painting and environment

- The microorganisms adopted are nonpathogenic and not spore forming 


\title{
BIOCLEANING OF NITRATE ALTERATIONS ON WALL PAINTINGS BY PSEUDOMONAS STUTZERI
}

\author{
Pilar Bosch Roig ${ }^{1}$, Jose Luis Regidor Ros ${ }^{1}$, Rosa Montes Estellés ${ }^{2}$. \\ ${ }^{1}$ Instituto Universitario de Restauración del Patrimonio, Universidad Politécnica de Valencia. Camino \\ de Vera s/n 46022 Valencia, Spain. \\ 2área de Microbiología, Departamento de Biotecnología, Universidad Politécnica de Valencia. Camino \\ de Vera s/n 46022 Valencia, Spain.
}

Corresponding author: Pilar Bosch Roig, pboschroig@gmail.com; TIf: 0034 677987401; Postal address: IRP. Camino de Vera s/n 46022 Valencia, Spain.

ABSTRACT: The microorganisms have been considered as causative agents of biodeterioration in multiple art works; however, they can be positively used for cleaning of salt crusts difficult to remove by traditional restoration methods. Here we use Pseudomonas stutzeri to efficiently clean wall paintings. These bacteria are able to efficiently remove in a homogenous way insoluble salt efflorescence without damaging the painting layer by using a new application support consisting in agar. This new technology has been successfully applied for the biocleaning of an eighteen century murals in a lunette of the Santos Juanes Church of Valencia, Spain.

Keywords: Biocleaning, Pseudomonas stutzeri, Bacteria, Mural Painting, Santos Juanes church, Nitrate-reducing bacteria.

\section{INTRODUCTION}

The formation of salt efflorescence on the surface of wall paintings is one of the most important mechanisms of art works deterioration on indoor environments. The precipitation of the salt exerts a pressure on the wall due to the increased volume of the crystals while growing. This situation generates traction forces that can exceed the strength of the material generating micro-cracks in the wall painting (Domenech and Yusa 2006).

These types of insoluble crusts are usually treated by restorers using physicochemical methods which in most of the cases are inadequate to the artwork since they are aggressive, invasive, non selective and require long application times. Moreover, the use of these methods can cause 1) changes in color, 2) movement of salts in the material structure, 3) excessive removal of original material... Likewise, these techniques often use toxic substances, exposing workers to a risk during treatment and introducing environmentally undesirable toxic elements (Cappitelli et al. 2007).

Microorganisms are generally considered responsible for the alteration in a number of art works (Sáiz-Jiménez and Samson 1981; Montes and Hernández 1999; Cappitelli et al. 2004), but can also have positive effects when used for conservation and restoration (Sáiz-Jiménez 1997; Webster and May 2006). The microorganisms selected for these approaches are always nonpathogenic and nonsporulated, not been a risk for workers neither for the art works. Microorganisms have cleaning advantages over the traditional physical-chemical cleaning treatments and enzymes, especially when the substances to remove are complex and incrusted. In these cases, the physical and chemical methods must be drastic and occasionally cause irreparable damage to the wall paintings. Enzymes due to their substrate-specific activity are not able to degrade complex substances, because it would require a mixture of enzymes very difficult to use together. Nevertheless, bacteria, thanks to its gene induction mechanisms, are able to adapt themselves to different environmental conditions and nutrients, synthesizing the enzymes they need to survive in any specific situation (Ranalli and Sorlini 2007). Biocleaning of wall painting has different advantages, compared with traditional restoration 
treatments, since they are non toxic, non aggressive, non invasive and highly specific. Besides, it has been reported that the use of microorganisms for the cleaning of work art is more efficient been able to clean more homogeneously and preserving intact the patina noble (Cappitelli et al. 2007; Sorlini and Cappitelli 2008). Another study comparing biocleaning process and other cleaning processes show that the use of bacteria was more economic than the use of enzymes like Protease and Collagenase (Ranalli et al. 2005).

Previous works have been used different bacteria to remove sulfate and nitrate crust from stone materials using bacteria like Desulfovibrio desulfuricans, Desulfovibrio vulgaris, Pseudomonas denitrificans, Pseudomonas stutzeri, Pseudomonas aeruginosa, Pseudomonas pseudoalcaligenes and Paracoccus denitrificans (Gauri et al. 1989; Heselmeyer et al. 1991; Ranalli et al. 1996 and 2000; Ranalli and Sorlini 2003; Cappitelli et al. 2006; Alfano et al. 2011).

But in the case of wall paintings, it has only been reported the use of Pseudomonas stutzeri to remove organic matter (Ranalli and Sorlini 2003; Antonioli et al. 2005; Ranalli et al. 2005; Sorlini and Cappitelli 2008; Polo et al. 2010). These previous works have been described different ways to expose the work art to the bacteria starting from the immersion of the art work in a solution with the bacteria, direct application of bacteria or by using delivery systems like cotton, sepiolite, Hydrobiogel-97, Carbogel and multilayer systems (Ranalli et al. 1997; Antonioli et al. 2005; Capitelli et al. 2006; Alfano et al. 2011). All these works have proved that the best way of applying the bacteria is by using a delivery system because it provided enough water for their survival but not too much as with immersion. An excess of water can produce damage to the art work (Campani et al. 2007).

This work show for the first time, the biocleaning of nitrate salt efflorescence from wall painting by using Pseudomonas stutzeri and the introduction of a new delivery system based on agar.

In particular the present research was carried out for the cleaning of insoluble salt efflorescence present on the wall paintings placed in the lunettes of the central vault of the Santos Juanes church in Valencia, Spain.

The Santos Juanes is a Baroque church that has its origins in the year 1240 as a conversion of a Muslim mosque and in 1942 was declared "Historic-Artistic National Monument" (see Fig. 1.). It is located in the old city center of Valencia and is one of the oldest and most important buildings of the city. This church has the biggest wall paintings found on Valencia of about 1200 square meters on the vault and lunettes carried out in 1693-1702 by the artists Antonio Palomino and Guilló. These wall paintings were done by the fresco technique where the pigments are applied with water and fixed to the lime and sand mortar by carbonation processes.

Due to the fires produced inside the church during the Spanish Civil War, 1936, these paintings were highly damaged, resulting in the loss of the $30 \%$ of the murals. The restoration of these paintings was commissioned to Gudiol (1958-1963), who pull off the paintings by strappo technique in three temporal phases. The techniques used by Gudiol turned out inadequate since it caused color changes leading to overview loss, and many other problems on the wall painting (Roig and Bosch 1990). One of the most important problems found in the murals was the formation of insoluble salt efflorescence. The salt formation process caused significant deterioration problems on the wall paintings since the processes of precipitation and crystal growth, exerts a pressure that caused micro-fractures on the wall and in the painting layer. The formation of salt efflorescence in these painting is due to an inter-vault space placed on the back of these murals. On this space, multiple rodents, birds and insects live and nest generating a large accumulation of organic waste. The nitrogen found on the organic matter when oxidation produce nitrates that with the rain water help, leak through the wall and form white efflorescence on the wall painting surface (Bosch et al. 2010). 
These crusts have been attempted to eliminate by physical and chemical techniques without obtaining the desired results because these traditional methods are complexes since they need different phases and reagents of different natures (like ion exchange resins). Here we propose an alternative methodology for the elimination of insoluble efflorescence, based on a biological way of cleaning.

\section{MATERIALS \& METHODS}

\subsection{Site description of church wall paintings}

The region selected for the on-site biocleanig was part of the third lunette on the north-west part of the church. The lunette general characteristics are: $25 \mathrm{~m}^{2}$ total area and inclination of 750 and 80. This region was picked up due to the presence of an extended white salt efflorescence covering most of the painted surface of the lunette.

\subsection{Sample preparation for optical analysis}

Micro-samples were taken by scalpel from lunettes before and after treatment and analyzed in the laboratory with optical microscopy and Cryo scanning electron microscopy. The samples for microscopy analysis were included in Serifix polyester resin (Struers) and then mechanically polished with abrasive disks (Struers, Erkrath, Germany) for a smooth transversal section. Light microscopy analysis have been done with a Leica DMR microscope with polarized light system for incident and transmitted light, and a stereoscopic microscope Leica GZ6, zoom (6-40x), vertical illumination with fiber optic ring Leica CLS 100 and Leica MPS 60 camera system. The samples for Cryo scanning electron microscopy (JEOL JSM5410 with a cryo-preparation Oxford Instruments CT1500C system) were rapidly frozen with liquid nitrogen (Beveridge and Graham 1991).

\subsection{Physico-chemical analysis}

Micro-samples were also physic-chemically analyzed by Infrared Spectroscopy Fourier Transform (FTIR) and lon Chromatography. FTIR for identification of inorganic compounds was done using a Vertex 70 (Bruker) with DTGS (deuterated triglycine sulfate) and the spectrum was obtained in absorbance mode, with a number of scans 32 and with a resolution of $4 \mathrm{~cm}-1$. The micro-samples were analyzed in ATR mode. Ion chromatography analysis (Metrohm equipped with Metrosep A SUPP 5 - 250 column) was carried out before and after the biocleaning process to evaluate the treatment efficacy (Ranalli et al. 1997; Capitelli et al. 2007).

Diverse nitrate reducing bacteria Pseudomonas stutzeri strains were tested in the laboratory for its best nitrate removal effectiveness. To detect the best strain removing nitrate, the Griess test and/or Nitrate Reductase Assay (Nitrate and Nitrite Merckoquant test strips) were used in the reduction of nitrate to nitrite and the presence of nitrogen formation in the Durham chamber after $48 \mathrm{~h}$ at $28 \circ \mathrm{C}$ in $10 \mathrm{ml}$ nitrate broth medium tube was studied (Griess. 1879; Cappuccino and Sherman 1992).

\subsection{Bacteria, media and cultural methods}

Nitrate reducing bacteria Pseudomonas stutzeri strains: 4899 (CECT), 930 (CECT), 5190 (DSMZ), 4166 (DSMZ) and 46326 (DSMZ) were tested in the laboratory for its best nitrate removal effectiveness. To do this test we growth one colony of each strain in $10 \mathrm{ml}$ tubes with Nitrate Broth culture medium at 28 ․ C. After $48 \mathrm{~h}$ we did different tests to each strain: ATP activity; molecular nitrogen gas formation capability; reduction of nitrate to nitrite ability; presence of nitrite and presence of nitrate on the culture medium as described in section 2.3. 
The selected Pseudomonas strain was growth in Nitrate Broth medium and incubated at $28{ }^{\circ} \mathrm{C}$ for 48 hours. Suspensions containing approximately $10^{10} \mathrm{CFU} \mathrm{ml}^{-1}$ exponentially growing bacteria were obtained by inoculating $100 \mathrm{ml}$ of an overnight Nitrate Broth-culture into a 1 l Nitrate Broth flask which was incubated at $28^{\circ} \mathrm{C}$ for $24 \mathrm{~h}$ in a shaker $(200 \mathrm{rpm}$ ). After centrifugation ( $3 \times 4200 \mathrm{rpm}$ for $10 \mathrm{~min}$ ) the pellet was washed twice with $\mathrm{NaCl} 0.8 \% \mathrm{pH} 7.0$ and re-suspended in sterile water. The final cell concentration was about $10^{10} \mathrm{CFU} \mathrm{ml} l^{-1}$; the suspension was immediately transported on ice with a cooled bag to the church for its application or stored at 4 으 for few days.

\subsection{Bacteria viability monitoring}

The microbial presence on the all-over treated surface, before treatment, just after treatment and one month later the biocleaning, was monitored.

Contact plates (with plate count agar), colony counts and total ATP assay (using a $3 \mathrm{M}^{\mathrm{TM}}{ }^{\mathrm{C}}$ Clean-Trace ${ }^{\mathrm{TM}}$ NG Luminometer) were carried out to monitor the bacteria viability and activity before and after the biocleaning treatments (Ranalli et al. 1998). Contact plates were incubated for $48 \mathrm{~h}$ at $28^{\circ} \mathrm{C}$ and colony were counted and expressed in colony forming units (CFU) per analyzed area (contact plates $55 \mathrm{~mm}$ ). To determine if the bacterial cells growth as colony formed units in Petri dished inoculated from the wall paintings were related to $P$. stutzeri, biochemical tests by API 20NE were adopted (Lalucat et al. 2006). Microbial growth was analyzed also by optic and electronic microscopy (CryoSEM). ATP activity was measured by luminescence and expressed in relative luminose unit (RLU) per $\mathrm{m}^{2}$ as responses of cell biomass activity.

\subsection{Laboratory tests on wall painting reproduction}

Different laboratory tests were carried out as a preliminary investigation. Stone material simulating wall paintings with salt efflorescence were used. To prepare the lab trials we used ceramic with a 1 $\mathrm{cm}$ layer of gypsum, a $3 \mathrm{~mm}$ layer of lime and sand (1:2) on top of it simulating the intonaco and over it we applied a painting layer with sand pigment according to the technique of buon fresco employed by the artist. For the generation of salt efflorescence, we rely on UNE-EN 12370 (1999): "Test methods for natural stone. Salt crystallization resistance determination". Following this methodology we inserted the lab trials in an oven at $60-100^{\circ} \mathrm{C}$ until obtain a constant mass. Then the lab trials were immersed in a saturated solution of potassium nitrate for 2 hours. Subsequently introduced into an oven at $60-100^{\circ} \mathrm{C}$ for 6 hours and left at room temperature about 13 hours. This process is repeated 3 times until whitish efflorescence appear on the surface (see Fig.2.). The concentration of nitrate used to do the lab trials was of $158 \mathrm{gl}^{-1}$, and the nitrate and nitrite tests (Merckoquant) done to the formed efflorescence showed concentrations of $0.5 \mathrm{~g}^{-1}$ (which is the maximum detection value of the test) and $0 \mathrm{~g}^{-1}$ respectively.

A uniform layer of $P$. stutzeri cells was applied on the lab trials with different carriers (cotton, sepiolite, carbogel, agar and agarose) using sterile flat brush. Before distribution of cell suspension, a japanese paper $\left(12 \mathrm{~g}\right.$ per $\left.\mathrm{m}^{2}\right)$ as a protection of the altered paint surface, was applied.

At different times ( $30 \mathrm{~min}, 90 \mathrm{~min}$ and $3 \mathrm{~h}$ ) at $28 \circ \mathrm{C}$ constant temperature and $70 \%$ relative humidity, using a controlled room chamber) laboratory tests were carried out. At the end of each treatment, the application supports were removed and the treated areas were carefully washed with a sponge impregnate with sterile distilled water. Analysis of nitrate salts was performed before and after the different treatments with Nitrate test strips (Merckoquant). Control tests were achieved with sterile water instead of bacteria suspension.

\subsection{Application supports}


Five different bacteria application supports were tested. Three of them were previously used in biorestoration: cotton (Antonioli et al. 2005; Ranalli et al. 2005), sepiolita (Ranalli et al. 1997 and 2000) and carbogel (Capitelli et al. 2006; Alfano et al. 2011); and the two ones were used for the first time in this field: agar and agarose. The protocol adopted in all cases was the same: 1) Japanese paper was first applied to protect the surface wall painting, 2) afterwards the bacterial suspensions were applied with a brush, and 3) on top of it the carrier was added. The cleaning system was removed at different fixed intervals with a sterile spatula and finally, the surface was cleaned and gentle brushed with sponge sterile water in order to remove the residual material.

\subsection{In-situ preliminary experiments on Santos Juanes church wall Paintings}

The area selected of the Santos Juanes church wall painting for the in-situ experiments was a lunette with one square meter surface covered with white salt efflorescence. The main chemical composition of the salt efflorescence was sampled and analyzed. Representative areas of around 10 $x 10 \mathrm{~cm}$ were selected and two tests were performed in triplicate: i) japanese paper $+P$. stutzeri DSMZ 5190 strain + agar; ii) japanese paper + water + agar as a negative control. The agar layers used in the preliminary test were circles of $90 \mathrm{~mm}$ diameter and $1 \mathrm{~cm}$ depth. The time were the bacteria were in contact with the surface of study was 90 minutes and in constant temperature of $25^{\circ} \mathrm{C} \pm 4$ 으 was maintained during the treatment to ensure a correct metabolic activity of the bacteria. After treatments, agar and japanese paper was removed and the surface was cleaned of bacteria with sterile water to avoid undesired metabolic processes and original material damage. The wall painting surface was dried at room temperature and micro-samples of all the control and biocleaned areas were taken for microbiological and chemical analysis.

\subsection{Large-scale biocleaning of the Santos Juanes church wall Paintings}

The area selected for the large-scale biocleaning was the same selected for the in-situ experiments. On the basis of preliminary analysis, we decided to extend the biocleaning process to the rest of the one square meter surface lunette following the same protocol described above. The lunette was fully-covered with Japanese paper, the $10^{10} \mathrm{CFU} \mathrm{ml^{-1 }}$ cell suspensions was applied over the paper with a sterile brush, and large agar layers were used to cover the entire surface. Treatment was kept for 90 minutes with constant temperature of $25^{\circ} \mathrm{C} \pm 4 \stackrel{\circ}{ } \mathrm{C}$, and after the established time, agar and Japanese paper were removed and the surface was carefully cleaned with sterile distillated water and let them to get dried. Afterwards samples of the biocleaned area were taken for microbiological and chemical analysis.

\subsection{Statistical analysis}

Diverse analyses of variance (ANOVA) were executed to evaluate the statistical significant differences between the control areas and the areas cleaned with bacteria. Results of statistical significant were shown by $\mathrm{P}$ values $<0.05$.

\section{RESULTS}

\subsection{Chemical composition of the salt efflorescence on the Santos Juanes wall paintings}

The main chemical composition of the salt efflorescence found in the Santos Juanes wall painting was potassium nitrate. It could be identified by the characteristic peaks $\left(2,397 \mathrm{~cm}^{-1}, 1,755 \mathrm{~cm}^{-1}, 1,352 \mathrm{~cm}^{-}\right.$ ${ }^{1}, 820 \mathrm{~cm}^{-1}$ y $535 \mathrm{~cm}^{-1}$ ) found on the infrared absorbance spectrum on the Fig. 3., and on the Ray $X$ SEM spectrum from a micro-sample were the $100 \%$ of the element found was potassium nitrate. Nitrate quantification of the salt efflorescence detected by lon chromatography show a average 
value concentration of $1,671.93 \mathrm{mg} \mathrm{kg}^{-1}$ and nitrate and nitrite tests strips (Merckoquant) concentration give us values of $0.5 \mathrm{gl}^{-1}$ and $0 \mathrm{gl}^{-1}$ respectively.

\subsection{Effectiveness of selected bacteria in biocleaning process}

For removal of nitrate salt crust from artistic surfaces, nitrate-reducing bacteria were used. These types of bacteria convert nitrates into molecular nitrogen, which is gas at room temperature and evaporate into the atmosphere (Ranalli and Sorlini 2003).

Preliminary results carried out at laboratory scale with six different strains (CECT 4899, CECT 930, DSMZ 5190, DSMZ 4166, DSMZ 46326) of nitrate reducing bacteria specie $P$. stutzeri, are summarized in Table 1.

These result showed that $P$. stutzeri DSMZ 5190 and CECT 930 strains showed better ATP activities at $48 \mathrm{~h}$ after growth on Nitrate Broth culture medium. These two strains were the only ones able to transform nitrate into molecular nitrogen gas. The three other strains (CECT 4899, DSMZ 4166 and DSMZ 46326) showed a nitrate transformation into nitrite, while DSMZ 5190 and CECT 930 strains did not reduce nitrate into nitrite but into molecular nitrogen (see Table 1).

On the basis of results comparing the bacterial ability to convert nitrate to nitrogen gas, we decided to adopt $P$. stutzeri strain DSMZ 5190 owing to the greater efficiency showed. In fact, $P$.stutzeri DSMZ 5190 strain was able to convert the double concentration (twice content) of nitrate into molecular nitrogen at slightly lower amount of bacteria $\left(9.1 * 10^{8} \mathrm{CFU} \mathrm{ml}^{-1}\right)$ than the P.stutzeri CECT 930 strain $\left(1.5 * 10^{9} \mathrm{CFU} \mathrm{ml^{-1 }}\right)$.

This can be evidenced because the strain DSMZ 5190 leave in the culture medium $0.025 \mathrm{gl}^{-1}$ of nitrate while the strain CECT 930 leave $0.05 \mathrm{gl}^{-1}$ (Table 1). The values of nitrate and nitrite used to prepare the normal Nitrate Broth medium (without bacterial growth) are $2 \mathrm{gl}^{-1}$ of nitrate and $0 \mathrm{gl}^{-1}$ of nitrite, as we confirm with the nitrate and nitrite test strips $\left(0.5 \mathrm{gl}^{-1}\right.$ and $0 \mathrm{gl}^{-1}$ respectively). These tests let us to conclude that, in our experimental conditions, bacterial cells of $P$. stutzeri strain DSMZ 5190 was the most efficient bacteria for bioremoving of Nitrate Salt efflorescence and therefore it was selected for the on-site biocleaning experiments.

\subsection{Salt efflorescence biocleaning of the lab trials}

Using simulating wall painting covered with salt efflorescence, we study which was the best application support for the bacteria and the best methodology and application conditions. Cotton, sepiolita (Pansil 100, CTS), carbogel (CTS), European bacteriological agar (Conda Lab S.A. Pronadisa) and agarose (Conda Lab S.A. Pronadisa) were tested with or without Japanese paper behind it. Hydrophilic and sterile wet cotton was applied to the lab trials as a homogeneous layer. Sepiolita was prepared diluting $60 \mathrm{~g}$ in distilled and sterile water, and carbogel was prepared to a final $2 \%$ concentration. In both cases $\mathrm{pH}$ was adjusted to 7 and carriers were applied to the lab trials with sterile spatula leaving a thin layer (2-4mm high). Agar and agarose powder were diluted in distilled water to a final concentration of $2 \%$ autoclaved and placed in plastic mold with the desired size to get a thin layer of $5 \mathrm{~mm}$ high.

These lab trial tests show that, in general, is more adequate to use Japanese paper because gives protection to the wall painting and allows a proper removing of the application supports. It is also observed that sepiolita and carbogel leave rests on the cleaned surface and can cause stains, confirming previous studies (Casanova 2008). Cotton, agar and agarose show better results when applied in horizontal surfaces (Bosch et al. 2011). However when assayed on vertical surfaces the 
cotton causes water marks due to water leak and produces a heterogeneous clean due to the gravity effect of water and bacteria accumulation at the bottom of the cotton (Fig. 4.). Nevertheless, agar and agarose don't leave marks or rest on the surface and clean homogeneously, showing better results. The fact that agarose is more expensive than agar decide to conduct the in-situ experiments using agar.

The trials on the laboratory also determine that the optimal time of treatment was 90minutes. On the assayed four different times 90 minutes, $3 \mathrm{~h}, 8 \mathrm{~h}$ and $24 \mathrm{~h}$, the cleaning results were good enough after 90 minutes treatment. These lab trials also let us to define an adequate biocleaning protocol by using Japanese paper to protect the painting layer.

\subsection{The use of agar carrier for biocleaning}

The agar carrier turned to be the most appropriate not only in the lab trial experiments but also in the on-site experiments. Agar shows good adhesive properties when applied onto different surfaces: horizontal, vertical and oblique, not showing any detachment from the wall during the time of the treatment. It also shows a valuable water and bacteria retention as we can see on Cryo-SEM observation (Fig.5.) and produce homogeneous clean not making stains and not leaving remnants of it on the cleaned surface.

\subsection{In-situ biocleaning of the salt efflorescence from the Santos Juanes wall paintings}

The area treated with bacteria covered a square meter and the wall painting on that area represents an eagle. Approximately $10^{10} \mathrm{CFU} \mathrm{ml^{-1 }}$ P. stutzeri DSMZ 5190 were directly applied in sterile water solution with a sterile brush over a Japanese paper. On top of it a thin ( $5 \mathrm{~mm}$ hight) $2 \%$ concentration agar layer, previously prepared on the laboratory with adequate plastic mold and carefully transported to the church, was placed to give the adequate humidity for the bacterial action. We use agar and water (without bacteria) as a negative control in different areas. The environmental temperature was maintained around $25^{\circ} \mathrm{C} \pm 4{ }^{\circ} \mathrm{C}$ during the treatment.

After 1 hour and 30 minutes of treatment, agar and Japanese paper was removed and the treated surface was delicately cleaned with sterile water. Strikingly, once the surface was dried we were able to notice that the salt efflorescence was completely disappeared (Fig. 6).

The nitrate content of the salt efflorescence in the surface of the wall paintings before any treatment measured by lonic chromatography was an average value of $1,671.03 \mathrm{mg} \mathrm{kg}^{-1}$ of sample. After cleaning with water and agar (negative control test) the surface content of nitrate was reduced to $561.315 \mathrm{mg} \mathrm{kg}^{-1}$. The wall painting surface nitrate content after the cleaning treatment with $P$. stutzeri DSMZ 5190 and agar was decreased till $133.82 \mathrm{mg} \mathrm{kg}^{-1}$, which is almost the same nitrate content present in the surface of a "healthy" (without salt efflorescence) wall painting $130.85 \mathrm{mg} \mathrm{kg}^{-1}$ (see Fig. 7.). There results show that nitrate removal was higher after cleaning with $P$. stutzeri DSMZ 5190 strain supported with agar, compared with the negative control (agar and water without bacteria), where a removal efficiency of $92 \%$ and $66.72 \%$ respectively, with significant difference $(\mathrm{P}<0.05)$ was calculated.

\subsection{Biocleaning monitoring}

The monitoring of the bacteria viability was done just after the treatment (after the fresco surface was dried) and one month from the end of the biocleaning treatment to verify that we do not leave bacteria alive on the surface of the art work.

ATP analysis and Contact plates microbial counts were analyzed showing the presence of few viable bacteria on the fresco surface. ATP media values obtained were 249 RLU per $\mathrm{m}^{2}$ just after the 
treatment and $2 \mathrm{RLU}$ per $\mathrm{m}^{2}$ one month after the treatment. The contact plate microbial counts media values were 0.0355 CFU per $\mathrm{m}^{2}$ and 0.022 CFU per $\mathrm{m}^{2}$ respectively (Table 2.). The average result of colony forming units (CFU) and ATP activity one month after the treatment don't show significant difference $(\mathrm{P}>0.05)$ to the ones obtained in the negative controls (not treated area) that were mean of $0.00425 \mathrm{CFU}$ per $\mathrm{m}^{2}$ and $13.9 \mathrm{RLU}$ per $\mathrm{m}^{2}$. These results show that the cleaning treatments applied to the wall painting (agar plus bacteria) after a month did not change the colony forming units normally present on the wall painting. Therefore, we conclude that the residual bacteria on the art work after the treatment is insignificant compared with the number of $P$. stutzeri applied solution used for the biocleaning treatment, which showed an ATP media value of 1716,980 $\mathrm{RLU}$ per $\mathrm{ml}^{-1}$ correlated to a viable cells media value of $10^{10} \mathrm{CFU} \mathrm{\textrm {ml } ^ { - 1 }}$.

We also check on the contact plates sampled one month after the treatment, the presence of $P$. stutzeri with biochemical API-20NE assays and the results were negative. Therefore we conclude that the biocleaning treatment did not leave any $P$. stutzeri on the cleaned surface.

\section{Discussion}

This work demonstrate that short term $(90 \mathrm{~min})$ application of $P$. stutzeri DSMZ 5190 in agar can give a good cleaning of insoluble nitrate efflorescence deposited on wall painting surfaces. As the lon chromatography proved a reduction of nitrate efflorescence of $92 \%$. We also show that agar is a successful application support for biocleaning of wall paintings, and we speculate that could be used in other mineral surfaces. Agar is able to give an adequate water supply to the bacteria, releasing the water only on the surface and with a uniform and controlled way without affecting the art work. The agar is reversible and does not leave any stain or residue on the art work, it is easy to apply and to remove at the end of the treatment, and it is no toxic for the people in his manipulation and environmental responsible. This new application support is able to reduce risks to the fresco also because minimizes the volume of water filtering inside the fresco and the time of contact. The fact that they clean so fast is important since it has been demonstrate that long periods of contact times causes damage to the art work like precipitation of sulfide acids when sulfate-reducing bacteria are used (Ranalli et al. 2000), or swelling and detachment of wall painting fragments (Lustrato et al. 2012).

We also show in this work, the importance of the short, middle and long term monitoring of the biocleaning treatment. The monitoring should be able to control that any $P$. stutzeri, water or rests of the application support (agar in this case) are leaved on the treated art work surface. Abundant rests of bacteria, water or agar on the treated surface could enhance the possibility that other microorganisms growth such us fungi that eventually could cause biodegradation in the wall painting. As we have exposed here, this can easily be avoided by a carefully clean and dry of the surface after the bacteria treatment.

Different researchers have recently published successful results of middle-long term bio-restoration monitoring. Ranalli et al. (2009) report a monitoring tree years after the bioremoval of animal glue from a Spinello Aretino fresco of the Monumental Cementery of the Camposanto in Pisa, confirming that the bio-cleaning technology is a safety alternative approach to conserve the Cultural Heritage. Alfano et al. (2011) have recently done a long term monitoring in the Matera Cathedral six years after the bioremoval of nitrates and sulfates from sandstone materials. They show that their treatments "did not supply nutrients that supported additional microbial growth" and that "the nitrate concentration remains stable". Besides, other groups have performed different approaches to monitor the microbial population dynamics before and after bio-consolidation treatments of limestone buildings (Ettenauer et al. 2011). These studies demonstrate that the biological treatments did not activate dangerous microorganisms but that the bio-restoration treatments can be able to change the microorganisms remaining on the treated areas. Our study also gives support to the 
safety of the biocleaning approaches for the art works, because not microorganisms' growth has been reported one month after the treatment.

Microbial monitoring can be achieved by traditional cultured techniques by using contact plates and microscope observations (optical microscopy and electronic microscopy). But we bet here for fast detection portable technology based on bioindicators like total ATP as a good monitoring tool because it let us know immediately in the field the microbial presence on the treated art work in a semi-quantitative way.

It is also very important to monitor the time evolution of nitrate concentration on the cleaned surface. The nitrate removal monitoring can be done by chemical analysis like Infrared analysis or Ionic Chromatography. The general disadvantage of this type of monitoring is that these analyses are micro-invasive and when working with valuable wall painting it's very difficult to take the sample for the analysis. New portable technologies like XRF (X-ray florescence) analyzer are every day appearing in the market minimizing the invasive techniques and decreasing the art work monitoring damage. Studies of the efficacy of this type of new technologies must be done to ensure its benefits and accuracy compared with traditional physical and chemical analysis.

However the good results showed here, we consider that further long-term monitoring analysis should be done in the Santos Juanes church of Valencia to evaluate the risks and benefits of the treatment. This analysis should be done in terms of microbial growth control, microbial population dynamics, and presence of efflorescence on the biocleaned wall painting surface.

This study revealed another successful application of biotechnology in the Cultural Heritage. In particular this work has established the basis of a new branch of the biotechnology applied to the restoration of wall paintings. This new technique permits, for the first time, the use of controlled bacteria to clean nitrate salt curst from wall painting surfaces. There are several important advantages in this technique such as it is fast, specific, no toxic, respectful with the art works and safe for the restorers (nonpathogenic microorganisms). This work also introduce for the first time, a novel application support based in agar showing to be a very adequate bacteria carrier for the biocleaning of wall painting. Some of the important characteristics of the agar are its uniform and controlled water supply, its ability of non stain or leave residues, and its non toxicity.

This type of biocleaning treatments should be evaluated in every specific case because each wall painting is different and each salt crust has its peculiar characteristics. The type of bacteria, the treatment time and conditions should be tested and adapted to each circumstance considering parameters like the chemical nature and thickness of the efflorescence.

\section{Conclusions}

In this work we use, for the first time, a biocleaning system based in P. stutzeri DSMZ 5190 and agar that efficaciously clean nitrate salt efflorescence from the wall paintings of the Santos Juanes church of Valencia, preserving the original pigments. This new biotechnological approach allows a noninvasive, specific and no toxic clean of wall painting that traditional cleaning treatments cannot do in such effective and respectful way. From our point of view, one of the most important advantages is the use of safe substances (not pathogenic bacteria and no toxic material) for the environment, the art work and the people. We hypothesized that this innovative biocleaning biotechnology, with the correct previous research, can be adapted for the cleaning of almost every type of compounds affecting Cultural Heritage, due to the fact that bacteria are able to synthesize inducible enzymes specifics to each case. 


\section{Acknowledgements}

This work was carried out with financial support partially received from the Universitat Politècnica de València (PAID-05-09: Biotecnología microbiana aplicada a la limpieza y restauración de superficies de obras de arte) coordinated by Rosa Maria Montes Estellés and the support of the Spanish Ministerio de Ciencia e Innovación with a PHD scholarship for Pilar Bosch Roig (BES-2006-12110). The autors wish to thank to the priest of the Santos Juanes Church of Valencia; to the "Dirección General de Patrimonio"; to Prof. Pilar Roig Picazo; to Gianluigi Colalucci, Donatella Zari and Carlo Giantomassi restorers of the Campo Santo di Pisa; to José Juan Baldo and Irene Carpio restorers of the Santos Juanes church of Valencia; to the Universitat Politècnica de València; to the Instituto Universitario de Restauración del Patrimonio; and to Restaura BioTech S.L.

\section{References}

Alfano, G., Lustrato, G., Belli, C., Zanardini, E., Cappitelli, F., Mello, E., Sorlini, C., Ranalli, G., 2011. The bioremoval of nitrate and sulfate alterations on artistic stonework: The case-study of Matera Cathedral after six years from the treatment. International Biodeterioration and Biodegradation 65(7), 1004-1011.

Antonioli, P., Zappararoli, G., Abbruscato, P. Sorlini, C., Ranalli, G., Righetti, P.G. 2005. Art-loving bugs: the resurrection of Spinello Aretino from Pisa's cemetery. Proteomics 5(9), 2453-2459.

Beveridge, T. J., and Graham, L. L. 1991. Surface layers of bacteria. Microbiol. Rev. 55, 684-705.

Bosch-Roig, P., Regidor-Ros, J.L., Soriano-Sancho, P., Doménech-Carbó, M.T., Montes-Estellés, R.M. 2010. “Ensayos de Biolimpieza con Bacterias en Pinturas Murales". Arché 4-5, 115-122.

Cappitelli, F., Zanardini, E., Sorlini, C., 2004. The Biodeterioration of synthetic resins used in conservation. Macromolecular Bioscience 4, 399-406.

Cappitelli, F., Zanardini, E., Ranalli, G., Mello, E., Sorlini, C., 2006. Improved methodology for bioremoval of black crusts on historical stone artworks by use of sulfate-reducing bacteria. Applied Environmental Microbiology 72, 3733-3737.

Cappitelli, F., Toniolo, L., Sansonetti, A., Gulotta, D., Ranalli, G., Zanardini, E., Sorlini, C., 2007. Advantages of using microbial technology over traditional chemical technology in the removal of black crusts from stone surfaces of historical monuments. Applied and Environmental Microbiology 73, 5671-5675.

Campani, E., Casoli, A., Cremoneso, P., Saccani, I., Signorini, E., 2007. L'uso di agarosio e agar per la preparazione di “Gel rigidi”. II prato (ed). Cesmar Vol 4, Padova

Cappuccino, J.G. and Sherman, N., 1992. Microbiology a Laboratory Manual. In: Benjamin/Cummings Inc. (3rd ed)

Casanoba-Beviá, I. 2008. Limpieza de obra mural mediante el uso de bacterias. Master Thesis, Polytechnic University of Valencia, Spain

Doménech-Carbó, M. T., and Yusá-Marco, D., J. 2006. Aspectos físicoquímicos de la pintura mural y su limpieza. Polytechnic University of Valencia (Ed) 
Ettenauer, J., Piñar, G., Sterflinger, K., Gonzalez-Muñoz, M.T., Jroundi, F. 2011. Molecular monitoring of the microbial dynamics occurring on historical limestone buildings during and after the in situ application of different bio-consolidation treatments. Science of the Total Environment 409, 53375352.

Gauri, L.K., Chowdhury, A.N., Kulshreshtha, N.P., Punuru, A.R., 1989. The sulfation of marble and the treatment of gypsum crusts. Studies in Conservation 34, 201-206.

Griess, P., 1879. Chem. Ber. 12, pp. 426

Heselmeyer, K., Fischer, U., Krumbein, W.F., Wascheid, T., 1991. Application of Desulfovibrio vulgaris for the bioconversion of rock gypsum crusts into calcite. In: BIOforum 1 / 2, 89.

Lalucat, J., Bennasar, A., Bosch, R., García-Valdés, E., Palleroni, N.J., 2006. Biology of Pseudomonas stutzeri. Microbiology and Molecular Biology Reviews 2, 510-547.

Lustrato, G., Alfano, G., Andreotti, A., Colombini, M.P., Ranalli, G. 2012. Fast Biocleaning of medieval frescoes. International Biodegradation and Biodeterioration, article in press. doi:10.1016/j.ibiod.2011.12.010.

Montes, R. and Hernández, E. 1999. Estudio de la contaminación microbiológica en la pinturas murales de la Basílica de la Virgen de los Desamparados de Valencia. In Roig, P. and Bosch, I., (Eds), Restauración de Pintura Mural aplicada a la Basílica de al Virgen de los Desamparados de Valencia. pp 201-215.

Polo, A., Cappitelli, F., Brusetti, L., Principi, P., Villa, F., Giacomucci, L., Ranalli, G., Sorlini, C., 2010. Feasibility of removing surface deposits on stone using biological and chemical remediation methods. Microbial Ecology 60, 1-14.

Ranalli, G., Chiavarini, M., Guidetti, V., Marsala, F., Matteini, M., Zanardini, E., Sorlini,C., 1996. The use of microorganisms for the removal of nitrates and organic substances on artistic stoneworks. In: Riederer, J., (Ed.), Proceedings of the eighth International Congress on Deterioration and Conservation of Stone, Berlin, pp. 1415-1420.

Ranalli, G., Chiavarini, M., Guidetti, V., Marsala, F., Matteini, M., Zanardini, E., Sorlini, C., 1997. The use of microorganisms for the removal of sulphates on artistic stoneworks. International Biodeterioration and Biodegradation 40 (2-4), 255-261.

Ranalli, G., Recchiuti, J.E., Grazia, L., 1998. Bioluminescence and impedance monitoring to detect the activity of starter cultures during frozen storage. Annali di Microbiologia ed Enzimologia 48, 169-180.

Ranalli, G., Matteini, M., Tosini, I., Zanardini, E., Sorlini, C., 2000. Bioremediation on cultural heritage: removal of sulphates, nitrates and organic substances. In: Ciferri, O., Tiano, P., Mastromei, G. (Eds.), Of Microbes and Art: The Role Of Microbial Communities In The Degradation And Protection Of Cultural Heritage. Kluwer Academic-Plenum, New York, pp. 231-245.

Ranalli, G., Sorlini, C. 2003. Application of microorganisms for the deteriorates surfaces recovery. Coalition 6 (2), 2-4. 
Ranalli, G., Alfano, G., Belli, C., Lustrato, G., Bonadduce, I., Colombini, M.P., Zanardini, E., Abbruscato, P., Cappitelli, F., Sorlini, C., 2005. Biotechnology applied to cultural heritage: biorestoration of frescoes using viable bacterial cells and enzymes. Journal of Applied Microbiology 96, 73-83.

Ranalli, G., Lustrato, G., Alfano, G., Andreotti, A., 2009. Long-term microbial Monitoring of biocleaned wall paintings at Pisa. Annals of Microbiology 59, Special Issue p19.

Roig-Picazo, P., Bosch-Roig, I. 1990. La Iglesia de los Santos Juanes de Valencia, proceso de intervención pictórica 1936-1990. Polytechnic University of Valencia (Ed)

Saiz-Jimenez, C., Samson, R. A. 1981. Biodegradación de obras de arte. Hongos implicados en la degradación de los frescos del monasterio de la Rábida (Huelva). Bot. Macaronesica 8-9, 255-264.

Saiz-Jimenez, C., 1997. Biodeterioration vs Biodegradation: The role of microorganisms in the removal of pollutants deposited on historic buildings. International Biodeterioration and Biodegradation 40, 225-232.

Sorlini, C., Cappitelli, F., 2008. The application of viable bacteria for the biocleaning of Cultural Heritage surfaces. Coalition 15, 18-20.

UNE-EN 12370 (1999): "Test methods for natural stone. Salt crystallization resistance determination".

Webster, A., May, E., 2006. Bioremediation of weathered-building stone surface. Trends in Biotechnology 24, 255-260

\section{Figures \& tables:}

Fig. 1. Image of the main façade of the Santos Juanes Church of Valencia, Spain.

Fig. 2. Image of the lab trials simulating the wall paintings with salt efflorescence on it.

Fig. 3. Salt efflorescence found on the Santos Juanes wall painting lunettes a) optical microscopy; b) scanning electronic microscopy; c) infrared absorbance spectrum showing Potassium Nitrate as the main component.

Fig. 4. Marks produced on the wall paintings due to the water leak gravity effect giving a heterogeneous clean when cotton is used as a cleaning support in vertical surfaces.

Fig. 5. Cryo-Scaning electron microscopy observation of agar with Pseudomonas Stutzeri cells.

Fig. 6. Biocleaning with Pseudomonas stutzeri entrapped in agar of salt efflorescence present on the wall painting lunette of the Santos Juanes Church of Valencia, a) area before the treatment; $b$ ) area during the treatment; $c$ ) area after the treatment.

Fig.7. Nitrate surface concentration of the salt efflorescence present on Santos Juanes church wall paintings (Efflorescence); after the cleaning treatment with agar and water (Water); before the cleaning treatment with agar entrapping Pseudomonas stutzeri DSMZ 5190 (Biocleaning); and nitrate concentration in a wall painting without salt efflorescence (Healthy).

Table 1. Bacterial growth after 48 hours in $10 \mathrm{ml}$ Nitrate Broth medium at $28^{\circ} \mathrm{C}$, measured of total ATP content, nitrogen formation, nitrate reduction to nitrite, nitrite and nitrate presence. The CFU $\mathrm{ml}^{-1}$ values show the initial bacterial concentration added to the broth medium. 
623 Table 2.

624 Bacterial activity measured by total ATP content (RLU) per $\mathrm{m}^{2}$ and viable counts (CFU) per $\mathrm{m}^{2}$ present 625 on the wall painting surface before and after the biocleaning treatment; and one month after the 626 treatment.

627 


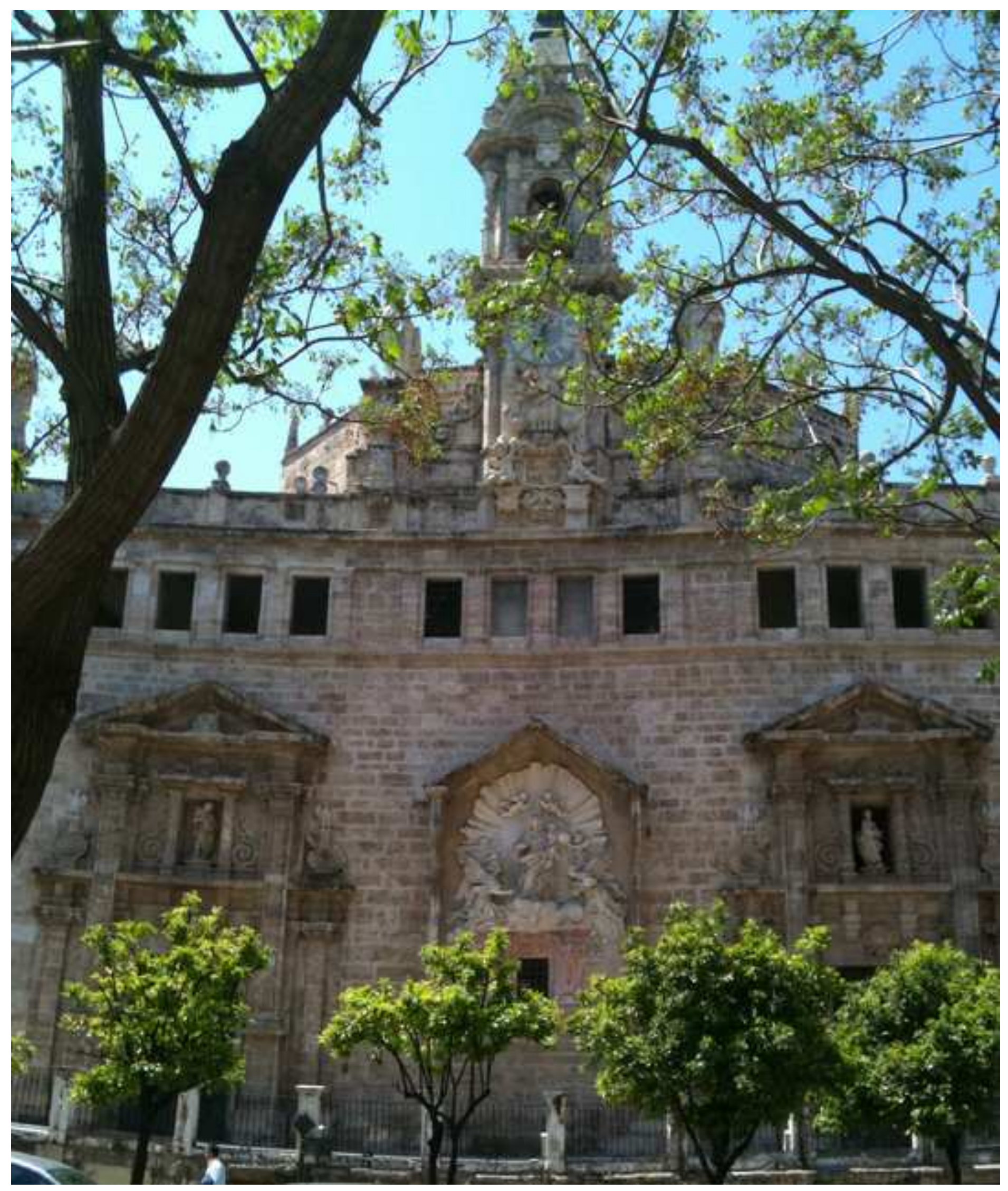


Click here to download high resolution image

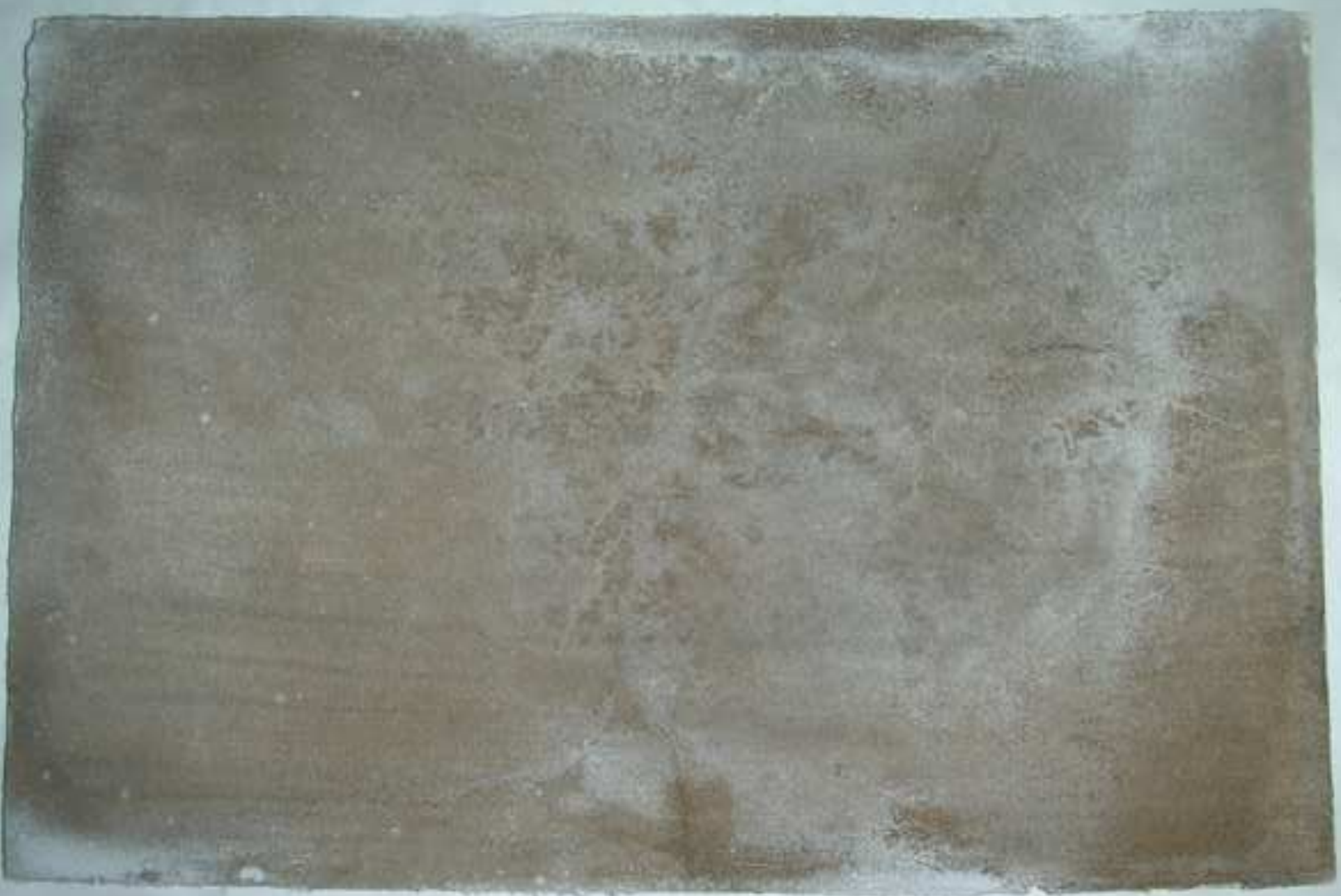




\section{Figure}

Click here to download high resolution image
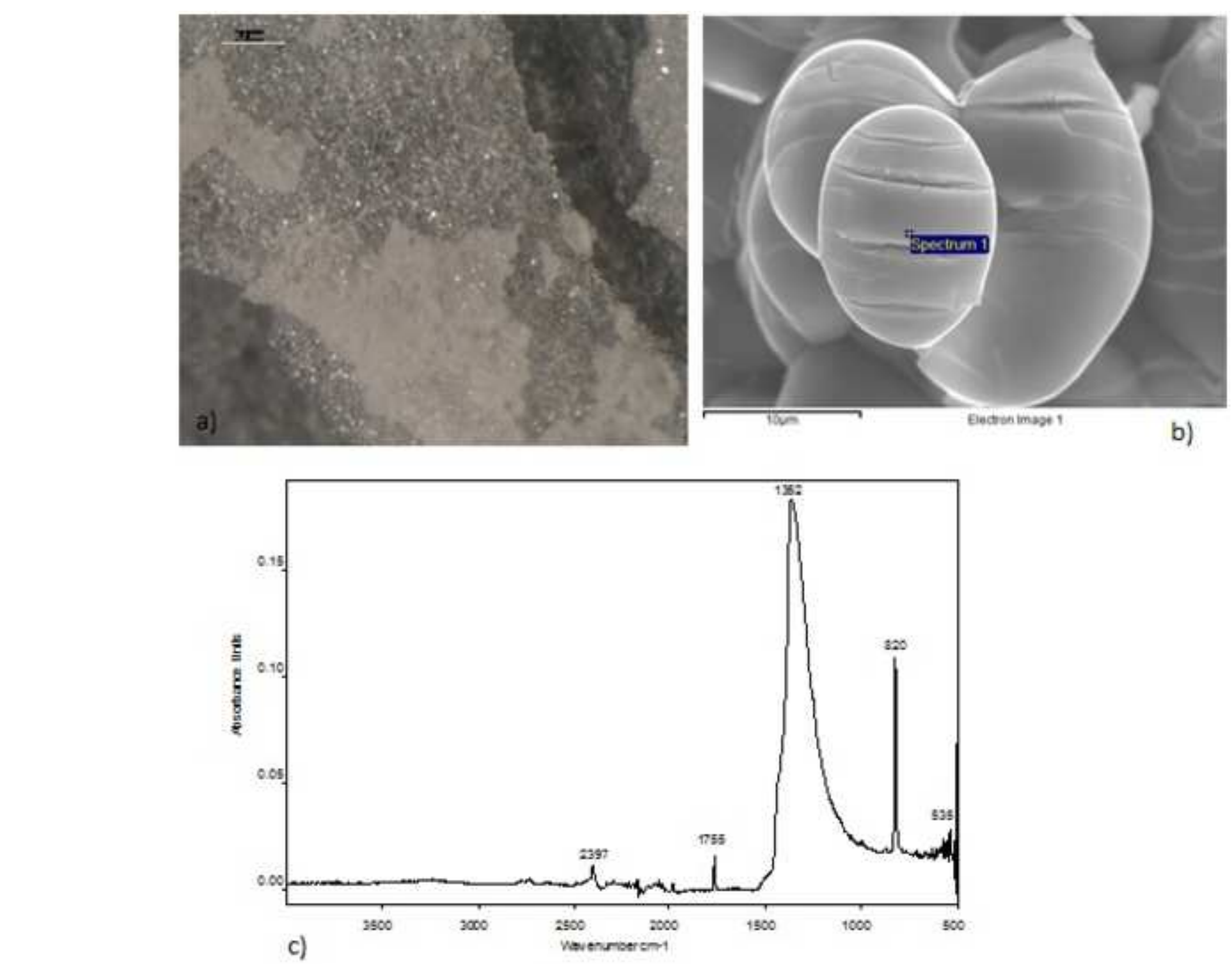


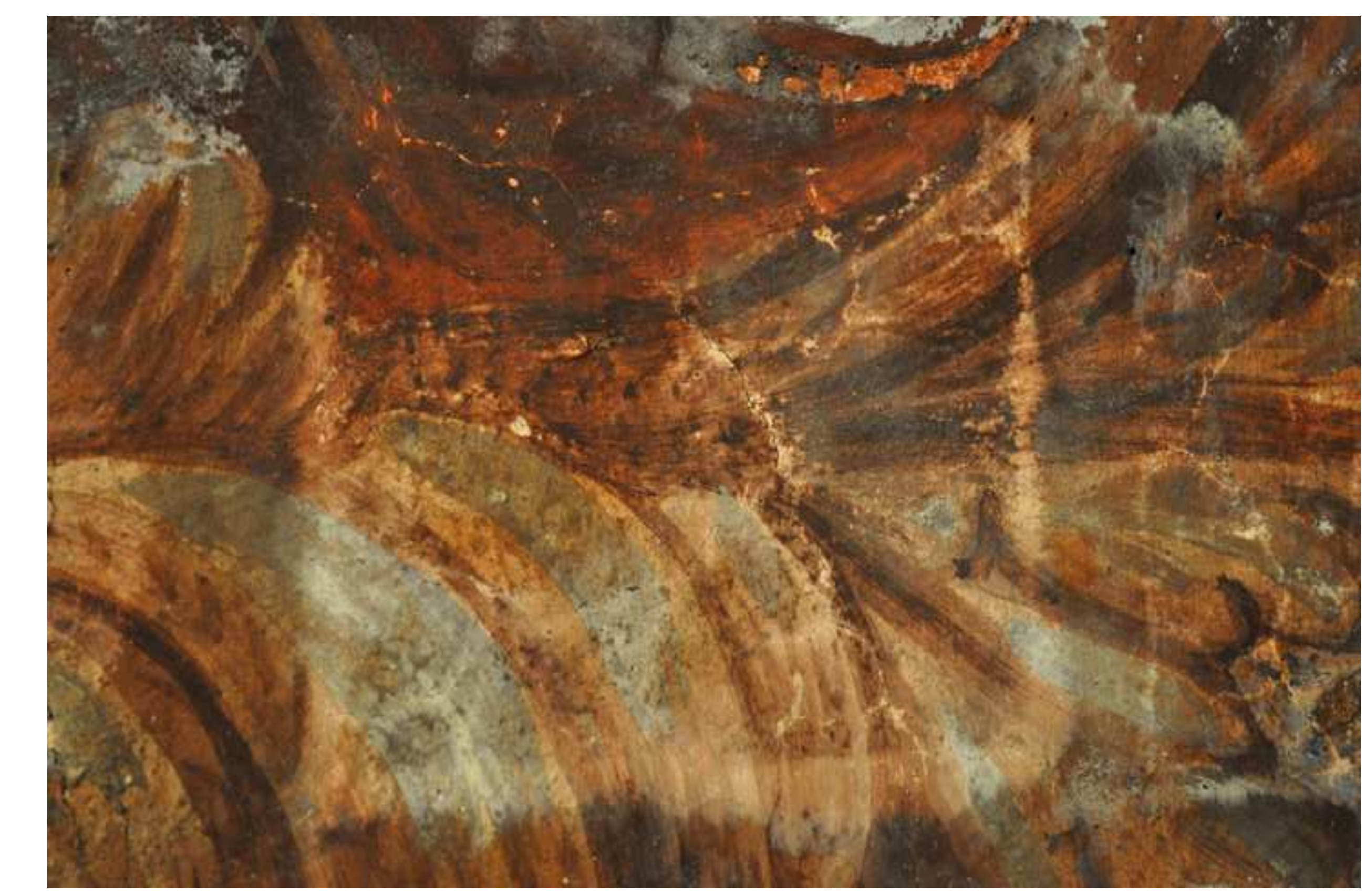

Clck here to download high resolution inage

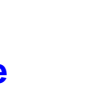
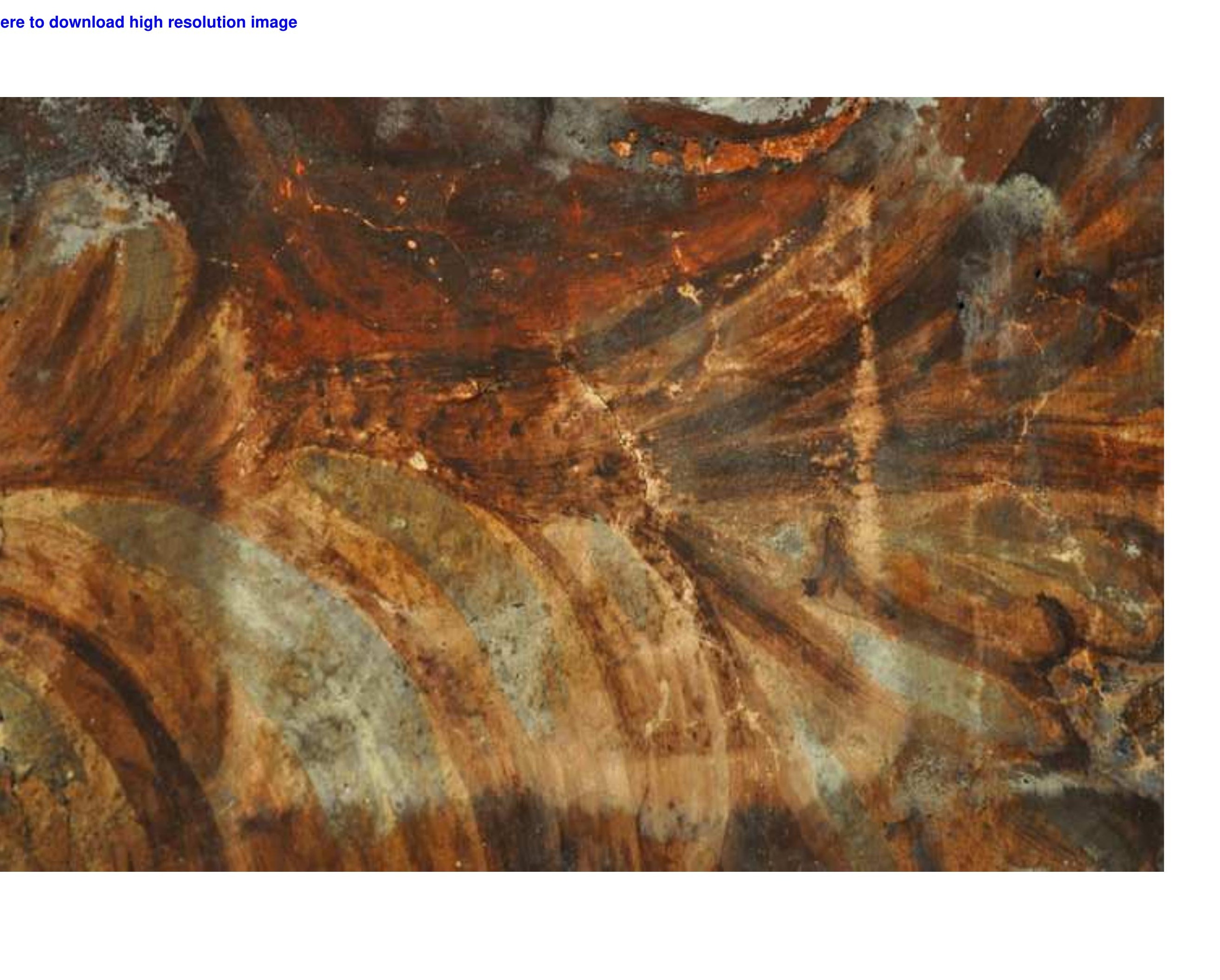
Click here to download high resolution image

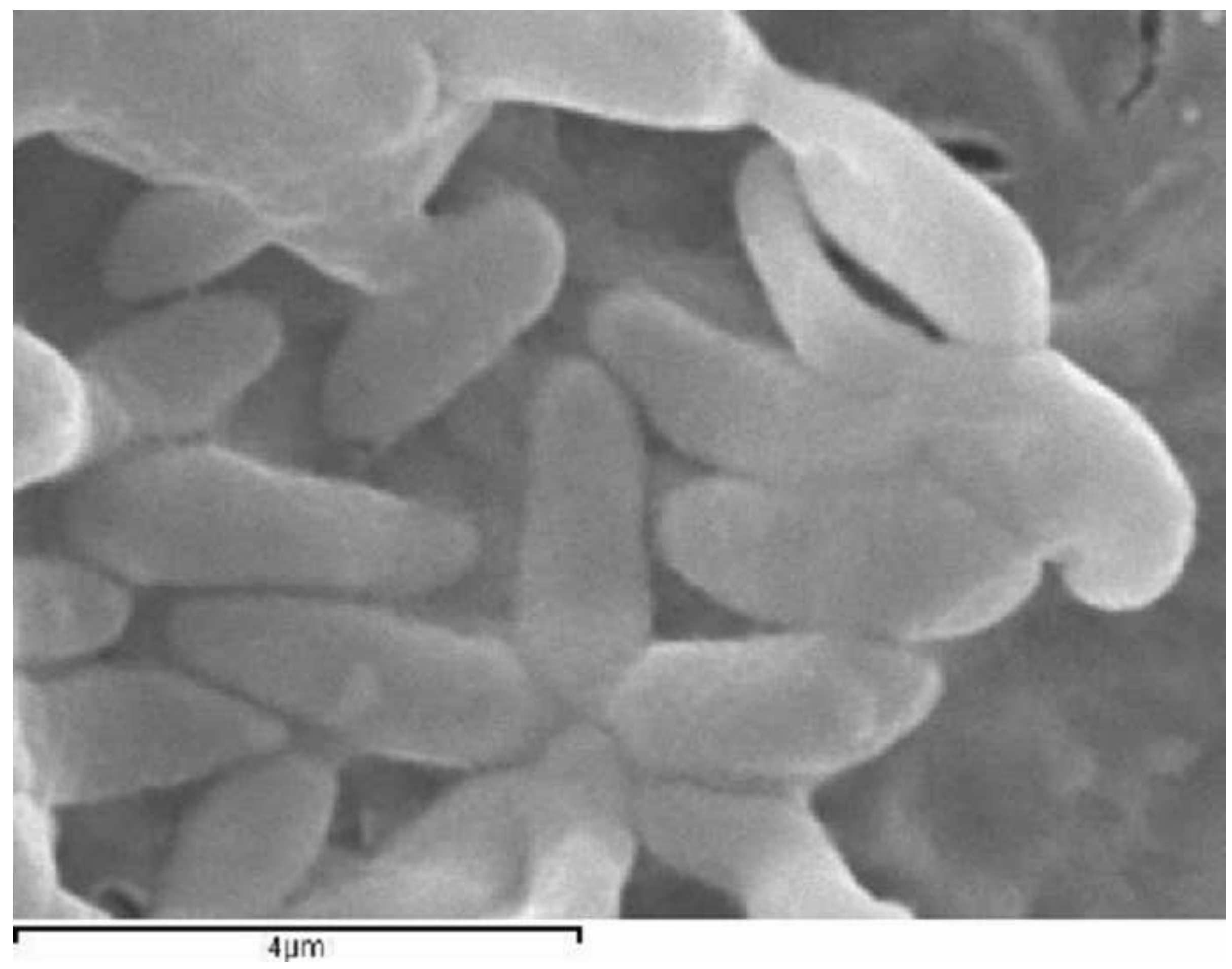


Click here to download high resolution image
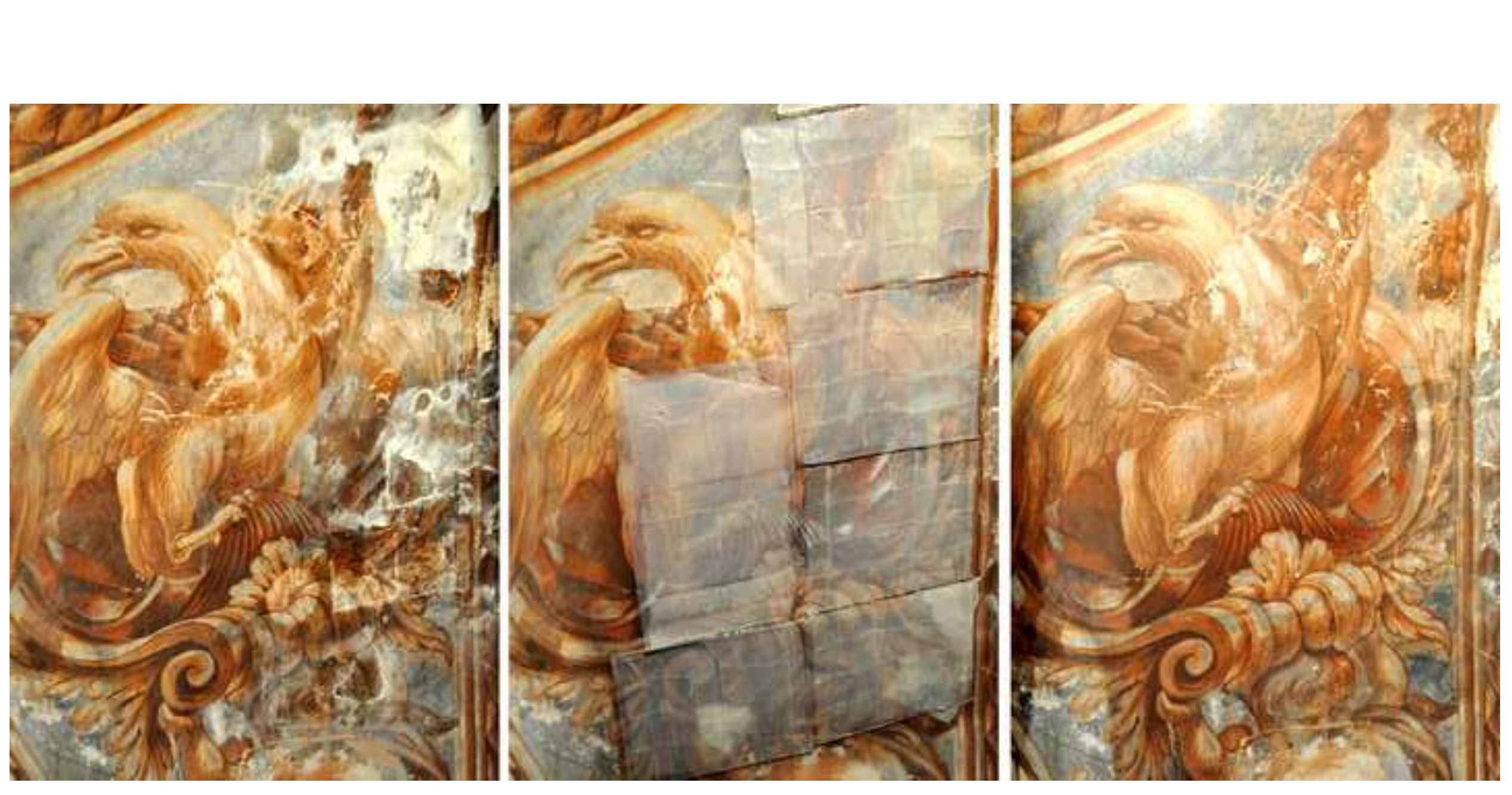


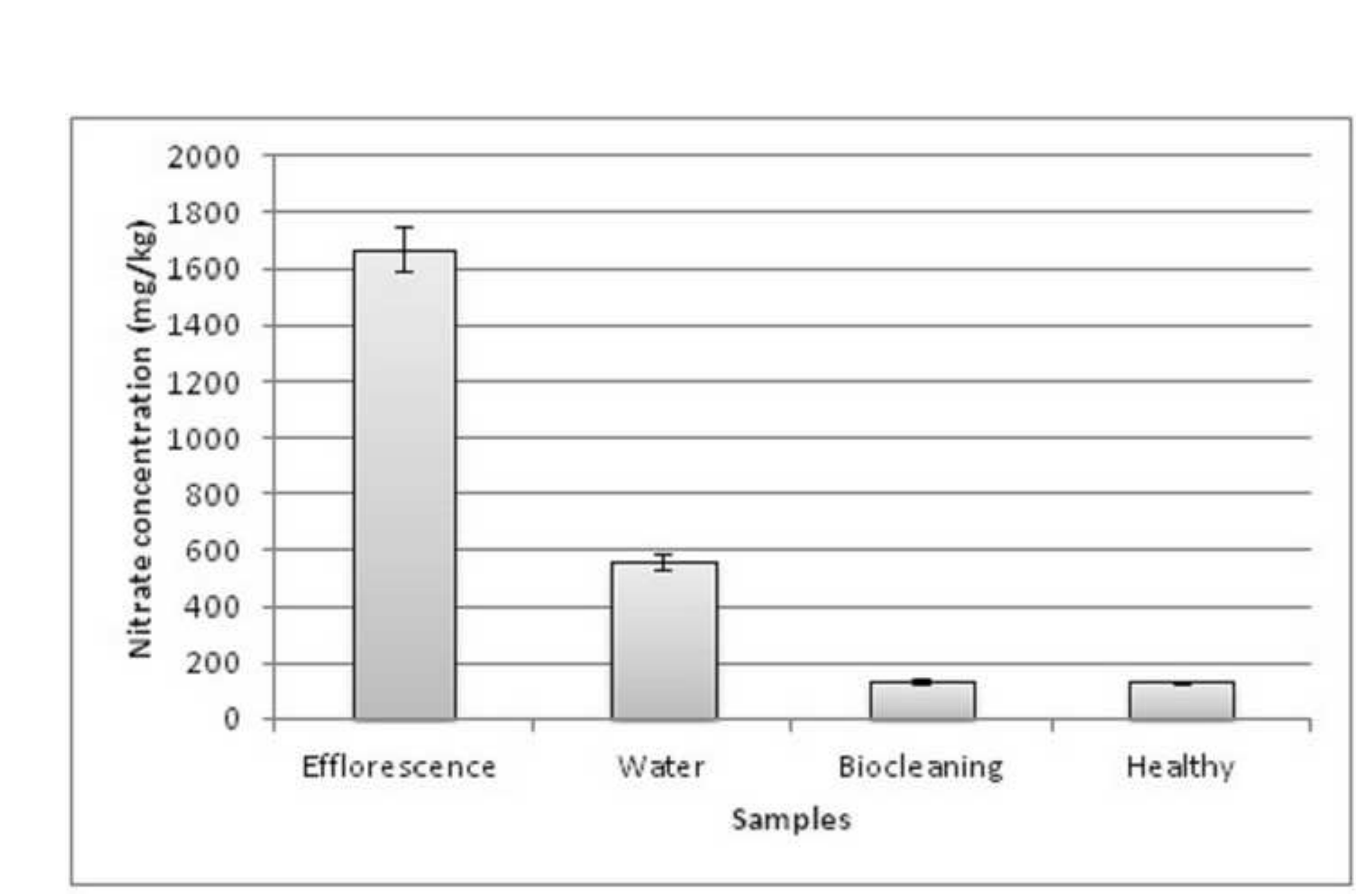

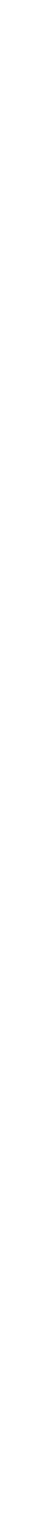

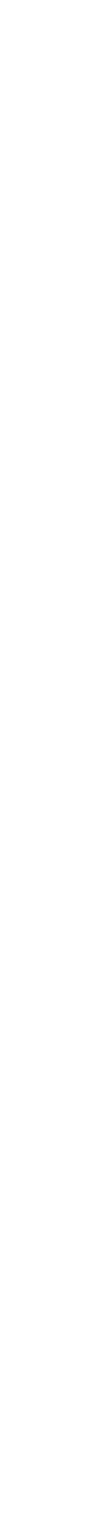


Table 1. Bacterial growth after 48 hours in $10 \mathrm{ml}$ Nitrate Broth medium at $28^{\circ} \mathrm{C}$, measured of total ATP content, nitrogen formation, nitrate reduction to nitrite, nitrite and nitrate presence. The CFU ml ${ }^{-1}$ values show the initial bacterial concentration added to the broth medium.

\begin{tabular}{|c|c|c|c|c|c|c|}
\hline \multirow[t]{2}{*}{$\begin{array}{l}\text { Bacteria } \\
\text { strain }\end{array}$} & \multirow[t]{2}{*}{$\mathrm{CFUml}^{-1}$} & $\begin{array}{l}\text { Total ATP } \\
\left(\text { RLUml }^{-1}\right)\end{array}$ & $\begin{array}{l}\text { Nitrogen } \\
\text { formation }\end{array}$ & $\begin{array}{l}\text { Nitrate } \\
\text { reduction } \\
\text { to nitrite }\end{array}$ & $\begin{array}{l}\text { Nitrite } \\
\text { presence } \\
\left(\mathrm{g}^{-1}\right)\end{array}$ & $\begin{array}{l}\text { Nitrate } \\
\text { presence } \\
\left(\mathrm{g} \mathrm{l}^{-1}\right)\end{array}$ \\
\hline & & \multicolumn{5}{|c|}{ Measures after 48 h growth at $28^{\circ} \mathrm{C}$} \\
\hline $\begin{array}{ll}P . \quad \text { stutzeri } \\
\text { CECT } 4899\end{array}$ & $1.2 * 10^{8}$ & 87,380 & - & + & 0.3 & 0.5 \\
\hline $\begin{array}{ll}P . \quad \text { stutzeri } \\
\text { CECT } 930\end{array}$ & $1.5 * 10^{9}$ & 247,450 & + & - & 0 & 0.05 \\
\hline $\begin{array}{ll}\text { P. } & \text { stutzeri } \\
\text { DSMZ } 5190\end{array}$ & $9.1 * 10^{8}$ & 112,690 & + & - & 0 & 0.025 \\
\hline $\begin{array}{ll}P . \quad & \text { stutzeri } \\
\text { DSMZ } 4166\end{array}$ & $8.8 * 10^{6}$ & 85,810 & - & + & 0.6 & 0.5 \\
\hline $\begin{array}{l}P . \quad \text { stutzeri } \\
\text { DSMZ } \\
46326\end{array}$ & 0 & 170 & - & + & 0.1 & 0.5 \\
\hline $\begin{array}{l}\text { Nitrate } \\
\text { Broth } \\
\text { without } \\
\text { bacteria }\end{array}$ & 0 & 0 & - & - & 0 & 0.5 \\
\hline
\end{tabular}

RLU, Relative Luminose Unit

+ , presence of nitrogen formation in the Durham chamber after $48 \mathrm{~h}$ growth in $10 \mathrm{ml}$ nitrate broth medium tube; or reduction of the nitrate to nitrite after Griess reagent reaction.

-, absence of nitrogen formation in the Durham chamber after $48 \mathrm{~h}$ growth in $10 \mathrm{ml}$ nitrate broth medium tube; or not presence of nitrite after Griess reagent reaction.

CFU ml ${ }^{-1}$, colony forming units of $P$. stutzeri inoculated to the nitrate broth medium.

Table 2.

Bacterial activity measured by total ATP content (RLU) per $\mathrm{m}^{2}$ and viable counts (CFU) per $\mathrm{m}^{2}$ present on the wall painting surface before and after the biocleaning treatment; and one month after the treatment.

\begin{tabular}{|l|c|c|c|}
\cline { 2 - 4 } \multicolumn{1}{c|}{} & \multicolumn{3}{c|}{ Bacterial activity } \\
\cline { 2 - 4 } \multicolumn{1}{c|}{} & Not treated area & After treatment & $\begin{array}{c}\text { One month after } \\
\text { treatment }\end{array}$ \\
\hline $\begin{array}{l}\text { ATP activity } \\
\left(\mathrm{RLU} / \mathrm{m}^{2}\right)\end{array}$ & $13.9 \pm 1.6$ & $249 \pm 80$ & $20 \pm 0.13$ \\
\hline $\begin{array}{l}\text { Viable counts } \\
\left(\mathrm{CFU} / \mathrm{m}^{2}\right)\end{array}$ & $0.00425 \pm 0.00468$ & $0.0355 \pm 0.016$ & $0.022 \pm 0.0204$ \\
\hline
\end{tabular}

